BIOMEDICAL AND BIOSOCIAL ANTHROPOLOGY
$\begin{gathered}\text { Official Journal of the International Academy } \\ \text { of Integrative Anthropology } \\ \text { journal homepage: http://bba-journal.com }\end{gathered}$

\title{
Hernioabdominoplasty after obstetric and gynecological operations in obese patients
}

Petrushenko V. V., Grebeniuk D. I., Kot A. O.

National Pirogov Memorial Medical University, Vinnytsya, Ukraine

\section{ARTICLE INFO}

Received: 29 March 2021

Accepted: 30 April 2021

UDC: $617.55-007.43-031.82-089-06-$ 089.844

CORRESPONDING AUTHOR e-mail: doctor.svo@gmail.com Grebeniuk D. I.
Statistics on the healing of obstetric and gynecological laparotomies with the formation of postoperative ventral hernias indicate a correlative and pathogenetic link with abdominal obesity in these patients, and inflammatory complications of subsequent corrective hernioplasty often have the same cause. The aim of the study was to improve the clinical and aesthetic results of surgical treatment of patients with hypogastric postoperative ventral hernias and scarring of the anterolateral abdominal wall on the background of abdominal obesity. The work is based on the analysis of paraoperative studies of 30 patients. The main group consisted of 19 patients who had umbilicalhypogastric postoperative ventral hernias of various sizes and locations after lower laparotomies or laparoscopic interventions. The comparison group included 11 patients who had only soft tissue deformities of the anterior abdominal wall without aponeurotic defects and hernias. Statistical processing of the results was performed using the software "Statistica 6.1". During the analysis of the obtained data it was found that parahernian excess tissues of the anterolateral abdominal wall after obstetric and gynecological operations have mainly supraaponeurotic localization and metric characteristics determined by the set size of the hernia, the severity of surrounding fatty layers and fibro-scar components. When performing hernioabdominoplasty in the conditions of ALAW obesity in patients with umbilical-hypogastric postoperative ventral hernias, sound tactics of dermolipectomy/fibrolipectomy were introduced in combination with abdominoplasty. This combination of surgical interventions reduces the incidence of local complications of hernia surgery to $4.5 \%$.

Keywords: postoperative hernias, obesity, dermolipectomy, hernioabdominoplasty.

\section{Introduction}

Statistics of healing of obstetric and gynecological laparotomies with the formation of postoperative ventral hernias $(\mathrm{POVH})$ indicate a correlative-pathogenetic link with abdominal obesity $(\mathrm{AO})$ of these patients, and inflammatory complications of subsequent corrective hernioplasty often have the same cause $[14,17]$. The substrate of their occurrence are adjacent adipose tissue with its own proinflammatory properties [11, 13], and not eliminated by herniation fibro-scar changes around the formed POVH hidden reservoirs of latent bacteria that can re-initiate purulent-inflammatory process in the aponeurotic plastics zone $[9,12,15]$. In this regard, laparoscopic technologies still have significant limitations in the treatment of POVH and do not significantly reduce the overall rates of local complications, which in comorbid AO reach $25-30 \%[2,6$, $8,18]$. Thus, surgical rehabilitation of patients with $\mathrm{POVH}$ with "excess" parahernial tissues is really associated with high risks of local complications and needs further improvement.

Hernioabdominoplasty (HAP) as a more correct method of surgical treatment of hypogastric hernias of previously operated obese women involves reconstructive intervention not only in the muscular aponeurotic layer (MAL), but also the soft tissue segment of their anterolateral abdominal wall (ALAW) in conditions of fat-related excess. But modern HAP with excision of surrounding "excess" and scarred tissues is usually performed without prior pathometric assessments, beyond any standards and based only on subjective inferences. Recently, from different clinical and pathogenetic positions, the therapeutic and prophylactic expediency of the calculated removals of parahernial tissues during open hernioplasty, including in $\mathrm{POVH}[5,7,11]$. This paper substantiates the practical algorithms of preoperative studies of tissue excesses of deformed ALAW in women 
and rational principles of their elimination to perform effective HAP.

The aim of the study was to improve the clinical and aesthetic results of surgical treatment of patients with hypogastric POVH and scarring deformities of ALAW on the background of abdominal obesity.

\section{Materials and methods}

The work is based on the analysis of paraoperative studies of 30 patients aged 26-54 years.

The main group (MG) consisted of 19 patients who had umbilical-hypogastric POVH of various sizes and localizations after lower laparotomies or laparoscopic interventions. The comparison group (CG) included 11 patients who had only soft tissue deformities of ALAW without aponeurotic defects and hernias.

Most of the women in the study group $(n=27)$ were overweight with a body mass index $>30 \mathrm{~kg} / \mathrm{m}^{2}$ and signs of "excess" adipose tissue ALAW of varying severity, including in the presence of polyetiological obesity I-III degree and/or AO with mostly subperitoneal fat deposits. The main criterion for ALAW obesity was considered to be its subcutaneous fat thickness $>4 \mathrm{~cm}$, because even with increased weight and abdominal circumference $>90 \mathrm{~cm}$ observed women with normal subcutaneous fat on the background of increased amounts of visceral fat only on ultrasound [18]. Components of total parahernial excess in MG patients were considered as pre-existing "ballast" adipose tissue ALAW (sometimes with visible "cellulite" changes as a manifestation of latent inflammatory process of subcutaneous fat of the abdomen, buttocks, thighs), and additional (herniogenic origin) $\mathrm{POVH}$, formed in the process of hernia expansion with stretching and inelastic deformation of the surrounding soft tissue peritoneal sac [19]. Their pathological components were considered to be skin scars, areas of lysis-fibrous thinning (ALFT), periligature granulomas or microabscesses, including fragments of sutures [18]. They were usually identified along with the aponeurotic defect, the edges of which were planned to be surgically joined and/or closed with alloplasty [14, 17]. In all examined women, the total excess of ALAW tissues in the area of previous obstetric and gynecological interventions corresponded to the concept of external abdominal deformity [3, 11, 19]. In MG, among such deformations, supraventricular protrusions were distinguished - herniogenic deformations (HD). In CG, deformities were represented by postoperative cicatricial deformities (SFD) and ventroptosis ("hernia-free control") non-hernia deformities (NHD).

MG patients with POVH $(n=19)$ are distributed depending on the "centric" hernia gate of their ALAW. The first subgroup of the main group (1SMG) consisted of 15 patients with hernias of anterior (odd) areas of medial localization: 12 umbilical-hypogastric POVH had near the projection of the former white line due to previous interventions due to various laparotomies and 3 trocar hernias after laparoscopic surgery. The second subgroup of the main group (2SMG) included 4 patients with POVH of lateral-lateral (paired) areas of ALAW, formed after iliac-pararectal access and tubo-ovarian surgery (including performed by surgeons with a previous diagnosis of "acute appendicitis"). Large hernias had 7 patients with a protrusion area greater than 1 anatomical area, small POVH on the background of obesity - 4 (3 of them trocar).

CG included 11 patients with NHD, of whom 3 had only excess fat deposits, mainly umbilical-hypogastric areas of ALAW in the form of a sagging abdomen (grade II-III ventroptosis) without previous history of surgery. The remaining patients $(n=8)$ had "apron-like" SFD after laparotomies, mainly due to retracted scars from healed Pfannenstiel-type accesses without herniation. All CG patients did not have aponeurotic defects and peritoneal sac, but were similarly examined for $\mathrm{POVH}$ as "hernia-free control." For aesthetic reasons and by agreement, they performed various calculated surgical excisions of excess (including scar) dermlipectomy/fibrolipectomy (DLE/FLE) in the form of preoperatively marked lipodermal flaps (LDF) together with abdominoplasty (AP or "mini"-AP) without reconstructive interventions in MAL [18].

The algorithm of metric studies of ALAW parahernial tissues before LDF marking, which was planned to be removed during herniation, initially included determining the thickness and height of supraaponeurotic folds above the hernia, determining the perimeter and area of protrusion, and two diameters of echoed hernia gate. Then, with the help of planimetric grid, geometric formulas and stereometric principles [1], supraaponeurotic volumes of hernial protrusion were determined, followed by deduction of herniogenic, ie hernia expansion, excess soft tissue [18, 19]. The set of "external" characteristics and dimensions was compared with the sonometric parameters of the MAL defect, also assessing the degree of dexterity of the hernia and the severity of the fixed deformation. In patients with $\mathrm{POVH}$ and diagnosed cumulative parahernial excesses, in addition to delineating the projection of the hernia gate on the skin, the size of ALFT was set [10, 11], which, when marked separately, added ideas about the volume of future DLE. The latter was usually performed in the first stage of herniation - as our improved surgical access to the aponeurotic defect and peritoneal sac with the removal of the established "excess" and pathological soft tissue environment. Excision of LDF by standardized ellipso-boatshaped block, including with deeper adipose tissue (paraportal fibrolipectomy (FLEP)) was performed with devices with a cutting-coagulation effect, thus preventing postoperative hemo-lymphorrhea and additional risk buildup. Technical features of DLE and AP simultaneous with different hernioplastics in volume excisions have been described by us earlier [11].

At the end of LDF removal or after the aponeurotic stage of hernioplasty, the "drug" was weighed to monitor the completeness of the calculated DLE and its correction if necessary. The latter was more often performed in the case 
of eccentrically widespread ALFT, including as a method of preventive remediation of the area of the next AP. Additional excision of ALFT was performed before FLEP and surgical correction of the edges of the MAL defect.

Intra-abdominal pressure (IAP) was measured transvesically by lberti-Kron [20] using a central venous pressure system attached to a Foley catheter. IAP monitoring was performed during and after all volumetric operations with DLEP/FLEP+AP, as well as the following day. Contraperture drainage with low vacuum lasted 1 day, and the tube was removed after cessation of exudate, often for 23 days. Antibiotic therapy was used according to standard principles $[18,19]$. The intensity of pain in operated women was assessed on a rating scale of 11 degrees ("Pain Rating Scale") daily up to 5 days before bedtime and before taking analgesics [10]. Functional results of operations and treatment were reflected in the criteria of good, satisfactory and unsatisfactory assessments [11].

Statistical processing of the results was performed using the software "Statistica 6.1".

\section{Results}

After concomitant use of DLE/FLEP+AP in hernia excision in $M G$ patients, including those with high $\mathrm{POVH}$, there were no fatalities or recurrences of hernias. In 1 such patient with high POVH who had dysmetabolic syndrome (obesity and type 2 diabetes), after HAP with DLEP+FLEP and the use of a synthetic implant, a loose paraprosthetic infiltrate was observed around the allohernioplasty area for a week and was conservatively removed.

The finding after the introduction of our tactics of simultaneous DLE/FLEP+AP significant reduction of local postoperative complications (up to $5 \%, p<0.05$ ) from various herniplasty in patients with POVH with obesity ALAW led to more detailed clinical and pathogenetic justifications.

The algorithm of preoperative measurements to determine the rational volumes of removal of parahernial tissues are given with specific examples in table 1.

Initially, such measurements were performed in comparison with the symmetrical intact area of ALAW in patients with 2SMG with "lateral-side" POVH - inguinal-pubic and lower-pararectal. In them standardly determined the thickness and height of the skin and subcutaneous folds (if necessary, the caliper) directly above the protrusion (including in repositioned hernia) and on the contralateral non-hernia area ALAW. The supraaponeurotic ultrasound height HD and its two diameters were sonometrically refined after previous cutaneous delineation of the hernial protrusion at abdominal tension and beyond. Based on the obtained data, the area (in $\left.\mathrm{cm}^{2}\right)$ and volume $\left(\mathrm{V}, \mathrm{cm}^{3}\right)$ of the protrusion, as well as the hernia $\mathrm{V}^{*}$-excess tissue formed as the difference between hernia and symmetrical intact areas of ALAW were calculated.

Preoperative differences in the volumes of supraaponeurotic tissues $\mathrm{V}$ and herniogenic excess tissues $\mathrm{V}^{*}$ (in $\mathrm{cm} 3$ and in percent) of 2SMG patients with specific lateral $\mathrm{POVH}$ according to the results of comparisons with data of contralateral non-hernia areas of their ALAW were as follows (see Table 1). In a patient with right-sided iliac $\mathrm{POVH}$ of medium size, $\mathrm{V}^{*}$ was $99 \mathrm{~cm} 3$ (which is about $+18 \%$ of "additional" tissues compared to the left), and in a patient with right-sided pararectal POVH on the background of grade III obesity - $397 \mathrm{~cm}^{3}$ (ie $+25 \%$ "excess" against the values of the symmetrical left-pararectal area). It should be noted that the severity of ALFT after wound healing from previous laparotomies in these patients were different. In the case of POVH after a previously performed lower pararectal laparotomy, when the edges of the "spiegel line" aponeurosis were sutured with PDS/0 monofilaments, prehealing was the primary tension and ALFT was virtually absent, requiring no additional attention in $V^{*}$ excess calculations. The need for additional calculations of the volumetric parameters of significant subcutaneous thinning arose in a patient with inguinal POVH with pronounced ALFT (as a result of suppuration with secondary wound healing after removal of pyosalpinx).

Serially analyzed by us by these algorithm indicators $\mathrm{V}^{*}$ as volume differences in different (primary and secondary) lateral-lateral hernias revealed some general patterns of formation of parahernial excesses as "additional" soft tissues ALAW, in particular, for the formed medium and large $\mathrm{POVH}$. This made it possible for each of these to derive and

Table 1. Algorithm with the results of comparative measurements of ALAW parahernial tissues in patients with "lateral-side" POVH.

\begin{tabular}{|l|c|c|c|c|}
\hline \multirow{2}{*}{$\begin{array}{c}\text { The nature of changes in ALAW } \\
\text { patients }\end{array}$} & \multicolumn{2}{|c|}{$\begin{array}{c}\text { POVH with HD "lateral-side" localizations } \\
\text { of ALAW }\end{array}$} & $\begin{array}{c}\text { Symmetrical areas of ALAW without hernias } \\
\text { and HD (intact) }\end{array}$ \\
\cline { 2 - 5 } & $\begin{array}{c}\text { llio-inguinal POVH } \\
\text { medium size }\end{array}$ & $\begin{array}{c}\text { Pararectal (lower) POVH } \\
\text { medium size }\end{array}$ & $\begin{array}{c}\text { Opposite } \\
\text { iliac area }\end{array}$ & $\begin{array}{c}\text { Opposite } \\
\text { pararectal area }\end{array}$ \\
\hline Fold thickness $(\mathrm{cm})$ & 6 & 9 & 5 & 7 \\
\hline Fold height $(\mathrm{cm})$ & 7,2 & 10,1 & 6 & 8 \\
\hline Ultrasound height of HD $(\mathrm{cm})$ & 6.5 & 8.8 & 5.5 & 7.5 \\
\hline Protruding diameters $(\mathrm{cm})$ & $10 / 13$ & $14 / 16$ & - & - \\
\hline Area (protrusion) $\left(\mathrm{cm}^{2}\right)$ & 102 & 176 & $/ 102$ & $/ 176$ \\
\hline $\mathrm{V}$ - tissue volume $\left(\mathrm{cm}^{3}\right)$ & 660 & 1550 & - & $/ 1153$ \\
\hline $\mathrm{V}^{*}$ - excess $\left(\mathrm{cm}^{3}(\%)\right)$ & $+99(18 \%)$ & $+397(25 \%)$ & & - \\
\hline
\end{tabular}


further use the generalized calculation coefficients of ALAW surpluses created by hernias with a range of their values from 0.1 to 0.3 . For hernias of medium size, the value of the excess coefficient is determined in the range of $0.15-0.25$; for large hernias - 0.25-0.35, and for giant - more than 0.35 . Coefficients reduced metric studies, especially in midparamedian $\mathrm{POVH}$ in $1 \mathrm{SMG}$, when the symmetrical ALAW region for comparisons was absent anatomically. The average values of these coefficients -0.2 and 0.3 , respectively, for medium and large hernias, thanks to the principle of extrapolation of the detected pattern [1], allowed simple measurements of any hernial protrusion simplified to set $\mathrm{V}^{*}$. A factor of 0.1 was used preoperatively in patients with trocar $\mathrm{POVH}$ who underwent hernioplasty with minimal DLE/FLEP.

For example, calculated in this way $\mathrm{V}^{*}$-excess ALAW over the former white line of the abdomen in a patient with umbilical-hypogastric POVH of medium size on the background of obesity I degree (used factor 0.2) was $138 \mathrm{~cm}^{3}$, and in a patient with large hypogastric POVH (after two cesarean section) and third-degree obesity (coefficient $0.3)$ preoperatively established $V^{*}$ was $1454 \mathrm{~cm}^{3}\left(1610 \mathrm{~cm}^{3}\right.$ minus the volume of ALFT). In both cases, intraoperative weighing of removed "drugs" coincided with previous mathematical calculations.

To create conditions for the simultaneous implementation of $\mathrm{AP}$, a rational method of removing excess parahernial tissues in $\mathrm{POVH}$ we have from different positions substantiated and used ellipso-boat (vertical or oblique) form of their excision and crescent-boat (horizontal) - in the middle and paramedian lobes-submedian hernias with SFD and ventroptosis. A separate study of the effects of $A P$ in the control CG showed that DLE+AP as a stand-alone operation without reconstructive interventions in MAL, does not cause its planar reduction and significant increases in IAP $(63.31 \pm 9.19 \mathrm{~mm}$ $\mathrm{Hg}$ relative to the normal range of $50-70 \mathrm{~mm} \mathrm{Hg}, \mathrm{p}>0.05)$. This was a factor in the vagueness noted here (3-4 points out of 11 possible) and short duration (2-3 days) of postoperative pain on the PRS scale. Therefore, DLE+AP as additional steps to the operation of hernioplasty in POVH in MG also did not adversely affect the oscillations of IAP $(76.81 \pm 11.93 \mathrm{~mm} \mathrm{Hg}$, $\mathrm{p}>0.05$ ) and did not significantly burden the "typical" (up to 6 points) pain syndrome, mainly due to surgical closure of the aponeurotic defect of the hernia gate.

Functional results after one-year follow-up in $M G$ were as follows: 17 hernia carriers operated with DLE/FLEP+AP had a good result, 2 patients had satisfactory results (both with 2SMG). The latter were due to: a feeling of discomfort in the area of mesh implantation in the first case, and due to scar pigmentation in the second. There were no unsatisfactory results, including aesthetic defects or cosmetic defects.

\section{Discussion}

The absence of fatalities and recurrences of hernias after concomitant use of DLE/FLEP+AP during herniation in MG patients, including those with large $\mathrm{POVH}$, indicates the safety of these simultaneous interventions even in conditions of additional paraoperative risks [14].

The set of data obtained by us showed that the required parameters measured in the hernia area only with the help of hands and rulers are close to sonometric. Therefore, in patients with hernias, volumetric parameters of parahernial tissues can always be determined by simple ventrometric examination. The need for ultrasound still arises in most $\mathrm{POVH}$ to clarify the prevalence of ALFT, which is due to the pathomorphosis of previous healing of the laparotomy wound on the substrate of which there was a hernia. Complementing the external measurements of sonometry with a linear ultrasound sensor also minimized the subjectivity of the determination of supraaponeurotic height, corrected the "median" and other dimensions and changes in the shape of the herniated protrusion and MAL defect, including in different positions of the patient. The latter was useful to improve the correctness of LDF markings before DLE with AP, due to the "sagging" displacement of large hernias [11, 18]. Ultrasound results also gave additional reason to believe that herniogenic deformities of ALAW of varying severity and depth have almost all patients with $\mathrm{POVH}$, including inconspicuous on the background of obesity small hernias. Therefore, even in the case of such, to determine the volume of ballast parahernial tissues before HAP, it is advisable to use a calculated factor of 0.1 in accordance with the specific size of the small hernia and the severity of obesity ALAW.

Simultaneous removal of the hernia defect and DLE+AP provided HAP with a positive mechanical effect on the area of aponeurotic plasticity by reproducing the effect of its "local bandaging" with soft tissues connected on top of it without leaving their excess. And the additional contact density created in this way between the superficial soft tissue layer of the operated ALAW and the area of aponeurosis plastics allowed to avoid the formation of fluid accumulations and other risks of local complications. This has significantly reduced the need for post-DLE/FLEP+AP use of antiinflammatory painkillers, expensive vacuum drainage devices, and long-term IAP monitoring. The obtained data confirmed the previous thesis that the statement of parahernial tissue excess before herniplasty and the use of metric estimation algorithm with correctly dosed removal during herniation are real components of the key to uncomplicated HAP [16].

Thus, clinically tested DLEP/FLEP+AP in patients with POVH with manifestations of $A O$ contribute to the therapeutic and aesthetic effectiveness of hernias after obstetrics and gynecology, improving the overall results of surgical rehabilitation and improving the quality of life of such patients [4]. Calculated removal of parahernial tissues with simultaneous AP as additions to standard aponeurotic hernioplasty in various POVH not only eliminates external deformation, but also prevents postoperative complications. The combination of the obtained results allows to offer 
HAP also as a general principle of surgical treatment of patients with umbilical-hypogastric $\mathrm{POVH}$ on the background of ALAW obesity.

\section{Conclusion}

1. Parahernial surpluses of ALAW tissues after obstetric and gynecological operations have mainly supraaponeurotic localization and metric characteristics determined by the totality of $\mathrm{POVH}$, the severity of the surrounding fat layers and fibro-scar components (ALFT), making up the volume of herniogenic in the range of $15-25 \%$ (with an estimated coefficient of 0.2 ), with large

\section{References}

[1] Avtandilov, A. I., Jabluchanskij, N. I., \& Gubenko, V. G. (1985). Системная стереометрия в изучении патологического процесca [Systemic stereometry in the study of the pathological process]. Москва: Медицина - Moscow: Medicine.

[2] Bittner, R., Bingener-Casey, J., Dietz, U., Fabian, M., Ferzli, G. S., Fortelny, R. H., ... \& Chowbey, P. (2014). Guidelines for laparoscopic treatment of ventral and incisional abdominal wall hernias (International Endohernia Society (IEHS)-part 1. Surgical endoscopy, 28(1), 2-29. doi: 10.1007/s00464-0133170-6

[3] Chevrel, J. P., \& Rath, A. M. (2000). Classification of incisional hernias of the abdominal wall. Hernia, 4(1), 7-11. doi: 10.1007/ BF01230581

[4] Criss, C. N., Petro, C. C., Krpata, D. M., Seafler, C. M., Lai, N., Fiutem, J., ... \& Rosen, M. J. (2014). Functional abdominal wall reconstruction improves core physiology and quality-of-life. Surgery, 156(1), 176-182. doi: 10.1016/j.surg.2014.04.010

[5] Davlatov, S. S. (2019). Оценка качества жизни в отдаленном периоде у больных с послеоперационными вентральными грыжами [Assessment of quality of life in the long term in patients with postoperative ventral hernias]. Шпитальна хірураія. Журнал імені І. Я. Ковальчука - Hospital surgery. Journal named after I. Kovalchuk, (2), 15-21. doi: 10.11603/2414-4533.2019.2.10413

[6] Feleshtynskyi, Ya. P., Dadaian, V. A., Zaritska, V. I. (2016). Особливості патогенезу та профрілактики троакарних гриж після лапароскопічної холецистектомії [Pathogenesis features and prevention of port-site hernias after laparoscopic cholecystectomy]. Вісник морфологіï - Reports of Morphology, 1(22), 101-106.

[7] Ganesh Kumar, N., Faqih, A. A., Feng, M. P., Miller, R. S., Pierce, R. A., Sharp, K. W., ... \& Poulose, B. K. (2017). Using Quality Improvement Principles to Enhance Long-Term Completion of Patient-Reported Outcomes after Ventral Hernia Repair. Journal of the American College of Surgeons, 224(2), 172179. doi: 10.1016/j.jamcollsurg.2016.10.031

[8] Grubnik, V. V., Nikitenko, R. P., Stepanovichus, O. M., \& Vorotyntseva, K. О. (2020). Переваги та недоліки лапароскопічних операцій при лікуванні вентральних гриж [Advantages and faults of laparoscopic operations in treatment of ventral hernias]. Клінічна хірургія - Klinichna khirurhiia, 87(3-4), 35-39. doi: 10.26779/2522-1396.2020.3-4.35

[9] Kalish, Ju. I. Ametov, L. Z., Shaiusupov, A. R., Yyhytalyev, S. Kh., \& Kabulov, M. K. (2016). Хроническая парапротезная инфекция после аллогерниопластики [Chronic paraprosthetic infection after allohernioplasty]. Медичні перспективи - Medical perspectives, 21(4) 62-66. doi: 10.26641/ hernias - $0.3(25-35 \%)$ and in the case of giant hernias on the background of $\mathrm{AO}>0.35$.

2. When performing HAP in ALAW obesity in patients with umbilical-hypogastric POVH, sound tactics of technically compatible with standard aponeurotic herniplasty DLE/FLEP +AP were introduced and the principle of their implementation was specified: "plastic without tension and excess tissue". Simultaneous DLE/ FLEP and AP reduce the incidence of local complications of hernias from $30 \%$ in standard operated hernias with obesity to $4.5 \%(p<0.05)$ according to the results of MG.

\section{7-0404.2016.4.90795}

[10] Koç, M., Tez, M., Yoldaş, O., Dizen, H., \& Göçmen, E. (2006). Cooling for the reduction of postoperative pain: prospective randomized study. Hernia : the journal of hernias and abdominal wall surgery, 10(2), 184-186. doi: 10.1007/s10029005-0062-2

[11] Kot, A. (2018). Симультанна дермліпектомія при хірургічному лікуванні хворих на грижі з абдомінальними проявами ожиріння [Simultaneous dermlipectomy in the surgical treatment of patients with hernias with abdominal obesity]. B матеріалах XXIV з'їзду хірургів України, присвяченому 100річчю О. О. Шалімова (стор. 90-94). Київ; ДУ "Національний інститут хірургії та трансплантації ім. О. О. Шалімова" - In the materials of the XXIV Congress of Surgeons of Ukraine, dedicated to the 100th anniversary of O. O. Shalimov (pp. 90-94). Kyiv; SI "National Institute of Surgery and Transplantation. O. O. Shalimov".

[12] Lambrecht, J. R., Vaktskjold, A., Trondsen, E., Øyen, O. M., \& Reiertsen, O. (2015). Laparoscopic ventral hernia repair: outcomes in primary versus incisional hernias: no effect of defect closure. Hernia: the journal of hernias and abdominal wall surgery, 19(3), 479-486. doi: 10.1007/s10029-015-1345$\mathrm{x}$

[13] Panchuk, O. V., Mishalov, V. H., Leshchyshyn, I. M., Simonov, V. F., Donets, Ye. H., Byk, P. L., \& Ohorodnik, T. O. (2018). Ліпоабдомінопластика в корекції дефектів черевної стінки [Lipoabdominoplasty in the correction of abdominal wall defects]. Хірургія України - Surgery of Ukraine, (4), 13-17. doi: 10.30978/SU2018-4-13

[14] Piatnochka, V. I., Dziubanovskyi, I. Ya., \& Prodan, A. M. (2018). Аналіз місцевих та загальних ускладнень при лікуванні первинних та післяопераційних вентральних гриж за період 2001-2017 pp. [Analysis of local and general complications in the treatment of primary and postoperative ventral hernias for the period 2001-2017]. Вісник наукових досліджень Bulletin of Scientific Research, (4), 66-73. doi: 10.11603/ 2415-8798.2018.4.9621

[15] Ramirez, O. M., Ruas, E., \& Dellon, A. L. (1990). "Components separation" method for closure of abdominal-wall defects: an anatomic and clinical study. Plastic and reconstructive surgery, 86(3), 519-526. doi: 10.1097/00006534-199009000-00023

[16] Ramshaw, B., Forman, B. R., Moore, K., Heidel, E., Fabian, M., Mancini, G., \& Joshi, G. P. (2017). Real-World Clinical Quality Improvement for Complex Abdominal Wall Reconstruction. Surgical technology international, (30), 155-164. PMID: 28085989

[17] Shamsiev, A. М., \& Davlatov, S. S. (2016). Хирургическое лечение больных вентральными грыжами с сопутству- 
ющим ожирением [Surgical treatment of patients with ventral hernias with concomitant obesity]. Шпитальна хірургія Hospital surgery, (1), 78-83. doi: 10.11603/24144533.2016.1.5882

[18] Surkov, N. A., Gushhin, A. V., Vladimirov, V. G. (2015). Ультразвуковая диагностика состояния поверхностных тканей передней брюшной стенки в реконструктивной и эстетической хирургии [Ultrasound diagnostics of the condition of the surface tissues of the anterior abdominal wall in reconstructive and aesthetic surgery]. Клинический вестник - Clinical bulletin, 1, 71-74.
[19] Tran, N. V., Petty, P. M., Bite, U., Clay, R. P., Johnson, C. H., \& Arnold, P. G. (2003). Tissue expansion-assisted closure of massive ventral hernias. Journal of the American College of Surgeons, 196(3), 484-488. doi: 10.1016/S10727515(02)01896-3

[20] Yi, M., Leng, Y., Bai, Y., Yao, G., \& Zhu, X. (2012). The evaluation of the effect of body positioning on intra-abdominal pressure measurement and the effect of intra-abdominal pressure at different body positioning on organ function and prognosis in critically ill patients. Journal of critical care, 27(2), 222.e1222.e2226. doi: 10.1016/j.jcrc.2011.08.010 